\title{
Determination of ramipril in human plasma and its fragmentation by UPLC-Q-TOF-MS with positive electrospray ionization
}

PAWEŁ SZPOT*

GRZEGORZ BUSZEWICZ

Laboratory of Forensic Toxicology

Medical University of Lublin

20-090 Lublin, Poland

\begin{abstract}
This report presents the application of ultra-performance liquid chromatography coupled to quadrupole time-of-flight mass spectrometry with positive electrospray ionization, to determine ramipril in human plasma. First, the proteins in human plasma were precipitated using acetonitrile, then the supernatant was extracted by ethyl acetate at $\mathrm{pH} 3$ and finally, the extract was analyzed using a UPLC-QTOF-MS system. The method was validated and the coefficient of determination $\left(R^{2}\right)$ was $>0.999$, the lower limit of quantification $(L L O Q)$ was $0.5 \mathrm{ng} \mathrm{mL} \mathrm{m}^{-1}$. Precision, recovery and stability were determined for three different concentrations of ramipril. RSD for this method ranged from 3.3 to $8.6 \%$. The intra-day mean recovery was from 65.3 to $97.3 \%$. In addition, the fragmentation of ramipril was studied. Due to high resolution of the spectrometer, it was possible to measure fragment masses accurately and determine their molecular and chemical formulas with high accuracy.
\end{abstract}

Keywords: ramipril, UPLC-Q-TOF-MS, fragmentation pathway

Ramipril is a specific angiotensin-converting enzyme (ACE) inhibitor. The drug is applied for all grades of hypertension (1). Ramipril is chemically designated as (2S,3aS,6aS)1-[(2S)-2-[[(2S)-1-ethoxy-1-oxo-4-phenylbutan-2-yl]amino]propanoyl]-3,3a,4,5,6,6a-hexahydro- $2 H$-cyclopenta[d]pyrrole-2-carboxylic acid. The major metabolite of ramipril is ramiprilat. Ramiprilat is formed by ester hydrolysis.

Ramipril was analyzed by various methods, such as spectrophotometry (2-4), atomic absorption (2), spectrofluorimetry (3), capillary electrophoresis (5), HPLC with a photodiode array detector (6), supercritical fluid chromatographic technique (7), gas chromatography-mass spectrometry (GC-MS) (8), liquid chromatography-mass spectrometry (LCMS) (9-17). However, some of these methods were characterized by high limit of detection or their results provided little information about fragmentation of the compound. Solid

\footnotetext{
*Correspondence; e-mail: pawel.szpot@umlub.pl
} 
phase extraction was most often used for isolation of ramipril from human plasma (8-11, 13, 16). Ramipril can be also successfully isolated by liquid-liquid extraction with a 70/30 $(V / V)$ diethyl ether/dichloromethane mixture (1), ethyl acetate (15), or after protein precipitation with methanol (17).

Broecker et al. (18) identified ramipril using ultra-performance liquid chromatography coupled to quadrupole time-of-flight tandem mass spectrometry (UPLC-Q-TOF-MS) but have not investigated its fragmentation pathway. UPLC-Q-TOF-MS is more selective and sensitive than the commonly employed techniques such as single quadrupole mass spectrometry due to its high accuracy of mass determination. This technique allows to identify metabolites and products of drug degradation (19-22). This novel technique can be used for accurate measurement of compounds and their fragments.

The objective of this paper was to develop a method for determining ramipril in human plasma and to study its fragmentation. In addition, we propose the possible pathway of ramipril fragmentation based on MS/MS spectra.

\section{EXPERIMENTAL}

\section{Chemicals and reagents}

Water, acetonitrile, methanol (Chromasolv ${ }^{\circledR}$ LC-MS, Fluka, Germany), ramipril (HPLC, Sigma-Aldrich, Germany) ethyl acetate (HPLC grade, AppliChem, Germany), formic acid (Fluka), diazepam-D5 (Cerilliant, USA) and ammonium chloride (Sigma-Aldrich, Germany) were used.

\section{Instrumentation}

Chromatographic analysis was performed using an ultra-performance liquid chromatograph (UPLC 1290, Agilent Technologies, Germany). The separation was done employing a Poroshell 120 EC-C18 column $3.0 \times 100 \mathrm{~mm} ; 2.7 \mu \mathrm{m}$ (Agilent Technologies, USA) with a thermostat at $40{ }^{\circ} \mathrm{C}$. A mixture of $0.1 \%$ formic acid in water (A) and $0.1 \%$ formic acid in acetonitrile (B) was used as a mobile phase. Gradient elution was carried out at a constant flow of $0.4 \mathrm{~mL} \mathrm{~min}^{-1}$. The following gradient was applied: 0 min $95 \% \mathrm{~A}(5 \% \mathrm{~B})$, $0-5 \min 30 \% \mathrm{~A}(70 \% \mathrm{~B}), 5-7 \min 0 \% \mathrm{~A}(100 \% \mathrm{~B})$ and then $7-8.5 \min 100 \% \mathrm{~A}(0 \% \mathrm{~B})$. Return to the starting gradient composition ( $95 \% \mathrm{~A}$ and $5 \% \mathrm{~B}$ ) was performed at $4 \mathrm{~min}$. The injected volume was $10 \mu \mathrm{L}$.

Detection of the investigated compounds was achieved using a quadrupole coupled to time-of-flight analyzer (Q-TOF-MS 6540, Agilent Technologies, USA). The spectrometer was equipped with an ESI Jet Stream source; identification and determination of the investigated drug was carried out in the SCAN mode. Operating spectrometer parameters are presented in Table I.

\section{Stock solutions, blank material and calibration standards}

Standard solutions of ramipril and diazepam-D5 were prepared in methanol. All solutions were stored at $-20^{\circ} \mathrm{C}$. 
P. Szpot and G. Buszewicz: Determination of ramipril in human plasma and its fragmentation by UPLC-Q-TOF-MS with positive electrospray ionization, Acta Pharm. 65 (2015) 159-169.

Table I. Spectrometer operating parameters

\begin{tabular}{ll}
\hline Spectrometer operating mode & Extended dynamic range $(2 \mathrm{GHz})$ \\
\hline Reference masses $(\mathrm{m} / \mathrm{z})$ & 121.0509 \\
& 922.0098 \\
\hline & Fragmentor -200 \\
Voltage $(\mathrm{V})$ & VCap -4000 \\
& Skimmer -45 \\
& OCT $1 \mathrm{RF}$ Vpp -750 \\
\hline Ionization & ESI jet stream $($ positive ions $)$ \\
\hline & Gas temp. $-300{ }^{\circ} \mathrm{C}$ \\
& Drying gas $-10 \mathrm{~L} \mathrm{~min}{ }^{-1}$ \\
Source & Nebulizer $-241.3 \mathrm{kPa}\left(\mathrm{N}_{2}\right)$ \\
& Sheath gas temp. $-400^{\circ} \mathrm{C}$ \\
& Sheath gas flow $-12 \mathrm{~L} \mathrm{~min}{ }^{-1}$ \\
\hline Acquisition rate/time & Rate -5 spectra s ${ }^{-1}$ \\
\hline Mass range $(\mathrm{m} / \mathrm{z})$ & Time $-200 \mathrm{~ms} \mathrm{per} \mathrm{spectrum}$ \\
\hline
\end{tabular}

Blank samples of human plasma were derived from the patients of the Chair and Department of Gastroenterology with Endoscopic unit, Medical University of Lublin, Poland. Study design was approved by the Bioethics Committee, Medical University of Lublin.

Blank samples of human plasma were screened prior to spiking in order to ensure that they were free from ramipril. Standard curves were prepared by spiking blank human plasma to yield final concentrations of $0.5,1,5,10,25$, and $50 \mathrm{ng} \mathrm{mL}^{-1}$ for ramipril.

\section{Sample preparation}

Human plasma $(200 \mu \mathrm{L})$ was transferred to 1.5 -mL Eppendorf tube adding $20 \mu \mathrm{L}$ internal standard (diazepam-D5, concentration $250 \mathrm{ng} \mathrm{mL}^{-1}$ ). Protein precipitation was carried out adding $200 \mu \mathrm{L}$ of acetonitrile. After vortex mixing for $1 \mathrm{~min}$ and centrifugation for $15 \mathrm{~min}$ at $20627 \mathrm{~g}$ at $5^{\circ} \mathrm{C}$, all of the supernatant was transferred to $12-\mathrm{mL}$ test tubes, subsequently adding $200 \mu \mathrm{L}$ of buffer $\left(0.5 \mathrm{~mol} \mathrm{~L}^{-1}\right.$ ammonium chloride $\left.-\mathrm{pH} 3\right)$. Liquid-liquid extraction with ethyl acetate $(2 \mathrm{~mL})$ was carried out for $20 \mathrm{~min}$. Samples were centrifuged at $5039 \mathrm{~g}$ and the organic phase $(1.7 \mathrm{~mL})$ was transferred to 2-mL Eppendorf tube and evaporated to dryness under a stream of nitrogen (at $\left.45^{\circ} \mathrm{C}\right)$. The extract was dissolved in $25 \mu \mathrm{L}$ of $1: 1$ acetonitrile/water, $V / V$ ) mixture, transferred to silanized glass insert and analyzed by UPLC-Q-TOF-MS.

\section{Validation}

Linearity. - Linearity was evaluated by the analysis of ramipril standard solutions in final concentrations of $0.5,1,5,10,25$ and $50 \mathrm{ng} \mathrm{mL}^{-1}$. 
Precision. - Five repeats of spiked samples at $0.5,5$ and $25 \mathrm{ng} \mathrm{mL}^{-1}$ were analyzed with calibration samples in one batch. Relative standard deviation was calculated for each concentration.

Recovery. - Recovery of the analyte was evaluated at each of the three different concentrations, $0.5,5$ and $25 \mathrm{ng} \mathrm{mL}^{-1}$. The recovery was calculated at time zero and after 24 hours. The recovery of ramipril was determined using the ratio of analytical signal from five repeats of each ramipril extract concentration compared to the signal from non-extracted methanol standards of equal concentrations.

Stability. - At time zero by each of the tested samples (ramipril in human plasma at 0.5, $5,25 \mathrm{ng} \mathrm{mL}^{-1}$ ) was repeated analysed five times by LC-Q-TOF-MS. The samples were then stored at $5{ }^{\circ} \mathrm{C}$ in an autosampler and analyzed again after $24 \mathrm{~h}$.

\section{Fragmentation study}

Fragmentation analysis of ramipril in a concentration of $1.5 \mu \mathrm{g} \mathrm{mL} \mathrm{L}^{-1}$ was carried out by the MS/MS mode with spectral parameters: mass range $50-1000 \mathrm{~m} / \mathrm{z}$, acquisition rate 1.5 spectrum s ${ }^{-1}$ and collision energy $35 \mathrm{~V}$. Other spectrometric parameters are given in Table I. Detailed analysis of ramipril fragmentation was carried out using the Agilent MassHunter Qualitative Analysis B.06.00 software.

\section{RESULTS AND DISCUSSION}

\section{LC-Q-TOF-MS analysis}

Quantitative ions for ramipril and diazepam-D5 were $417.2384[\mathrm{M}+\mathrm{H}]^{+}$and 290.1103 $\left[\mathrm{M}+\mathrm{H}:{ }^{35} \mathrm{Cl}\right]^{+}$respectively. The ramipril confirmational ion of highest intensity was the 234.14886 [M- $\left.\mathrm{C}_{9} \mathrm{H}_{13} \mathrm{NO}_{3}\right]^{+}$ion. The qualitative ion for diazepam-D5 was its isotope ion $292.10735\left[\mathrm{M}+\mathrm{H}:{ }^{37} \mathrm{Cl}\right]^{+}$. Retention time for ramipril was $4.48 \mathrm{~min}$, for IS $5.8 \mathrm{~min}$. Fig. 1 shows that ramipril elutes when the intensity of matrix is relatively low. The highest intensity of the matrix can be seen on the chromatogram between 2 and $3.6 \mathrm{~min}$ and also after $6 \mathrm{~min}$. Due to the high specificity of detection (five decimal places for masses of investigated compounds), no interfering peaks were observed at the retention time of ramipril and IS. Thus it is possible to achieve high peak intensity and high sensitivity of the method, along with specificity.

\section{Validation and sensitivity parameters}

Linearity. - The linear concentration range is from 0.5 to $50 \mathrm{ng} \mathrm{mL}^{-1}$ for ramipril. The coefficient of determination $\left(R^{2}\right)$ was $>0.999$. The calibration line equation was $y=1.007888$ $x-0.012159$. The lower dynamic range in comparison to triple quadrupole mass spectrometry is a consequence of ion saturation at the upper part of the concentration range. It particularly refers to the compounds that have a chloride atom in their structure. However, therapeutic concentrations of ramipril according to TIAFT (The International Association of Forensic Toxicologists) $1-10 \mathrm{ng} \mathrm{mL}^{-1}$ are within the range of calibration curve.

$L L O Q$ is defined as the lowest validated spike level meeting the method performance acceptability criteria (mean recoveries for each representative commodity in the range 


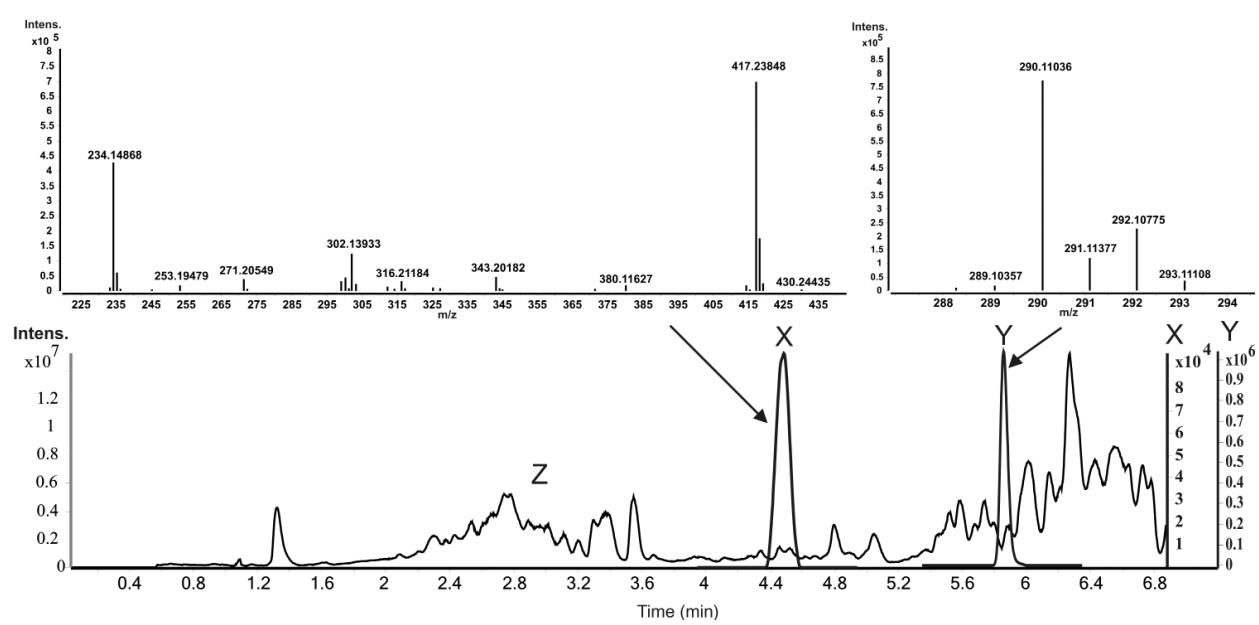

Fig. 1. Q-TOF-MS spectrum and extract ion chromatogram (EIC) of ramipril (X) and diazepam-D5 (Y). Total ion chromatogram $(Z)$.

$70-120 \%$, with a RSD $\leq 20 \%$ ). A $L L O Q$ of ramipril in human plasma was determined to be $0.5 \mathrm{ng} \mathrm{mL} \mathrm{mL}^{-1}$. Limiting values evaluation based on the signal-to-noise ratio can be applied to analytical methods that exhibit baseline noise. Application of the Q-TOF-MS detection system achives an HPLC chromatogram without baseline noise. During the extraction of ramipril ion (with accuracy of up to $20 \mathrm{ppm}$ ) the signal-to-noise was formal infinite for each calibration point. Such situations have already been described $(23,24)$.

Precision. - RSD data obtained from five plasma repetitive measurements of three spiked plasma samples $\left(0.5,5,25 \mathrm{ng} \mathrm{mL}^{-1}\right.$ ramipril) ranged from $3.3-8.6 \%$.

Recovery and stability. - The results of stability and recovery of ramipril in plasma are shown in Table II. At time zero, mean recovery was from 65.3 to $97.3 \%$ whereas inter-day recovery ranged from 66.0 to $100.0 \%$. The intra-day RSD was lower than inter-day RSD at each concentration. As expected the highest decrease of precision was detected for the lowest concentration of $0.5 \mathrm{ng} \mathrm{mL}^{-1}$.

Table II. Stability of ramipril in human serum ${ }^{a}$

\begin{tabular}{|c|c|c|c|c|c|c|c|}
\hline & \multirow[b]{2}{*}{$\begin{array}{l}\text { Nominal } \\
\text { concentration } \\
\left(\mathrm{ng} \mathrm{mL} \mathrm{mL}^{-1}\right)\end{array}$} & \multicolumn{3}{|c|}{$t=0$} & \multicolumn{3}{|c|}{$t=24 \mathrm{~h}$} \\
\hline & & $\begin{array}{c}\text { Found } \\
\text { concentration } \\
\left(\text { mean, ng mL } \mathrm{mL}^{-1}\right)\end{array}$ & $\begin{array}{l}\text { Mean } \\
\text { recovery } \\
(\%)\end{array}$ & $\begin{array}{c}\text { RSD } \\
(\%)\end{array}$ & $\begin{array}{c}\text { Found } \\
\text { concentration } \\
\left(\text { mean, ng mL } \mathrm{mL}^{-1}\right)\end{array}$ & $\begin{array}{l}\text { Mean } \\
\text { recovery } \\
(\%)\end{array}$ & $\begin{array}{c}\text { RSD } \\
(\%)\end{array}$ \\
\hline \multirow{3}{*}{ 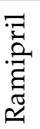 } & 0.5 & 0.68 & 71.3 & 8.6 & 0.63 & 66.0 & 17.1 \\
\hline & 5 & 4.72 & 65.3 & 3.3 & 4.87 & 70.0 & 3.6 \\
\hline & 25 & 23.92 & 97.3 & 6.1 & 24.55 & 100.0 & 6.2 \\
\hline
\end{tabular}

${ }^{\mathrm{a}} n=5$. 


\section{Mass studies of the fragmentation pattern for ramipril}

The data from MS ${ }^{\mathrm{n}}$ studies (Table III) helped to propose the fragmentation pathway of ramipril (Fig. 2.) We conducted an MS/MS analysis of four precursor ions, $m / z$ 417.2384, 343.20162, 234.14886 and 156.10191. The molecular ion peak of ramipril (417.2384) fragmented in $\mathrm{MS}^{2}$ into ten ions of $\mathrm{m} / \mathrm{z} 343.20162,234.14886,206.11756,160.11208,156.10191,134.09643$, $130.08626,117.06988,110.09643,102.05495$. In other MS $^{n}$ steps, some of which are repeated, we observed that there are two ways of fragment 117.06988 formation: the first $343.20162 \rightarrow 117.06988$ and the second $234.14886 \rightarrow 117.06988$, but only one way of formation of 102.05495 (234.14886 $\rightarrow 102.05495)$. Ion 343.20162 was formed when ramipril lost ethylformate while ion 234.14886 was formed during the hydrolysis of amide.

Fig. 2 shows total mass fragments of ramipril obtained in a Q-TOF-MS/MS study. Due to the high resolution of the spectrometer we could propose the molecular formula for

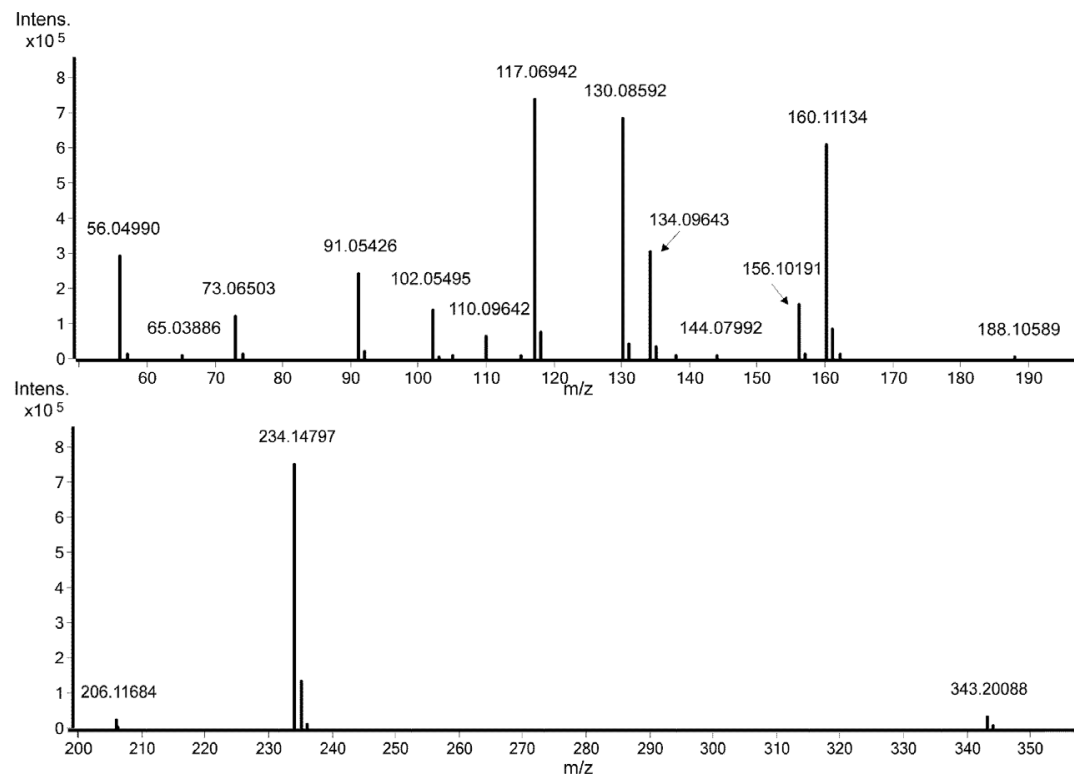

Fig. 2. (+) ESI MS² spectrum of ramipril $[\mathrm{M}+\mathrm{H}]^{+}=417.2384$

Table III. MS fragmentation of ramipril

\begin{tabular}{lll}
\hline MS $^{n}$ & Precursor ion $(m / z)$ & Product ion $(m / z)$ \\
\hline MS $^{2}$ & 417.2384 & $343.20162,234.14886,206.11756,160.11208,156.10191,134.09643$, \\
& & $130.08626,117.06988,110.09643,102.05495$ \\
MS $^{3}$ & 343.20162 & $160.11208,156.10191,117.06988,110.09643$ \\
MS $^{4}$ & 234.14886 & $130.08626,117.06988,102.05495$ \\
MS $^{5}$ & 156.10191 & 110.09643 \\
\hline
\end{tabular}


each fragment with high probability. Experimental mass for major fragments of ramipril, mass error in ppm (parts per million) and proposed elemental composition are shown in Table IV.

$$
\text { mass error }(\mathrm{ppm})=\frac{\text { experimental mass }- \text { theoretical mass }}{\text { theoretical mass }} \times 10^{6}
$$

Table IV. Observed $\mathrm{m} / \mathrm{z}$ values for the $[\mathrm{M}+\mathrm{H}]^{+}$ions and major fragments of ramipril

\begin{tabular}{ccccc}
\hline $\begin{array}{c}{[\mathrm{M}+\mathrm{H}]^{+}} \\
\left(t_{\mathrm{R}^{\prime}} \text { min) }\right.\end{array}$ & $\begin{array}{c}\text { Fragment ion } \\
\text { (theoretical mass) }\end{array}$ & $\begin{array}{c}\text { Fragment ion } \\
\text { (experimental mass) }\end{array}$ & $\begin{array}{c}\text { Error } \\
(\mathrm{ppm})\end{array}$ & $\begin{array}{c}\text { Proposed } \\
\text { composition }\end{array}$ \\
\hline 343.20162 & 343.20157 & 0.14 & $\mathrm{C}_{20} \mathrm{H}_{26} \mathrm{~N}_{2} \mathrm{O}_{3}$ \\
& 234.14886 & 234.14852 & 1.43 & $\mathrm{C}_{14} \mathrm{H}_{19} \mathrm{NO}_{2}$ \\
417.2384 & 206.11756 & 206.11684 & 3.47 & $\mathrm{C}_{12} \mathrm{H}_{15} \mathrm{NO}_{2}$ \\
$(4.48)$ & 160.11208 & 160.11180 & 1.16 & $\mathrm{C}_{11} \mathrm{H}_{13} \mathrm{~N}$ \\
& 156.10191 & 156.10193 & 0.48 & $\mathrm{C}_{8} \mathrm{H}_{13} \mathrm{NO}_{2}$ \\
& 134.09643 & 134.09643 & 0.03 & $\mathrm{C}_{9} \mathrm{H}_{11} \mathrm{~N}$ \\
& 130.08626 & 130.08592 & 2.58 & $\mathrm{C}_{6} \mathrm{H}_{11} \mathrm{NO}_{2}$ \\
& 117.06988 & 117.06969 & 1.59 & $\mathrm{C}_{9} \mathrm{H}_{8}$ \\
& 110.09643 & 110.09642 & 0.05 & $\mathrm{C}_{7} \mathrm{H}_{11} \mathrm{~N}$ \\
& 102.05495 & 102.05495 & 0.05 & $\mathrm{C}_{4} \mathrm{H}_{7} \mathrm{NO}_{2}$ \\
\hline
\end{tabular}

In the MS/MS spectrum, we observed four fragments of ramipril (234.14886, 160.11208, 130.08626 and 117.06988) of high intensity. These fragments may be successfully employed as confirmative ions in Q-TOF-MS/MS analysis.

Using the obtained MS/MS spectra and defined accurate masses we proposed the ramipril fragmentation pathway (Fig. 3). Fragmentation pathway of ramipril is very similar to the fragmentation pattern for trandolapril proposed by Dendeni et al. (25). However, we have not observed ions such as 280 (which would be the form of 234 ion) or 252 (which would be the form of 206 ion). The proposed fragmentation mechanism is based on the hydrolysis of amide and hydrolysis of ester, like in the trandolapril fragmentation pathway.

Table V. shows the comparison of the method presented in this paper to the results obtained by other authors. Three different techniques were used for the isolation of ramipril from biological material: precipitation with organic solvents, liquid-liquid extraction (LLE) and solid phase extraction (SPE). The use of SPE resulted in highest recovery rates (above $81 \%$ ). However, this method requires special columns and is time consuming. On the other hand, the recovery for methods that use only LLE with ethyl acetate was less than $70 \%$, which is also undesirable (15). In this article, we combined precipitation with acetonitrile and LLE with ethyl acetate, which resulted in a higher value for the recovery compared to the authors who used only ethyl acetate (15). Another aspect that has to be noted is the use of a variety of internal standards by other authors. All authors who used 


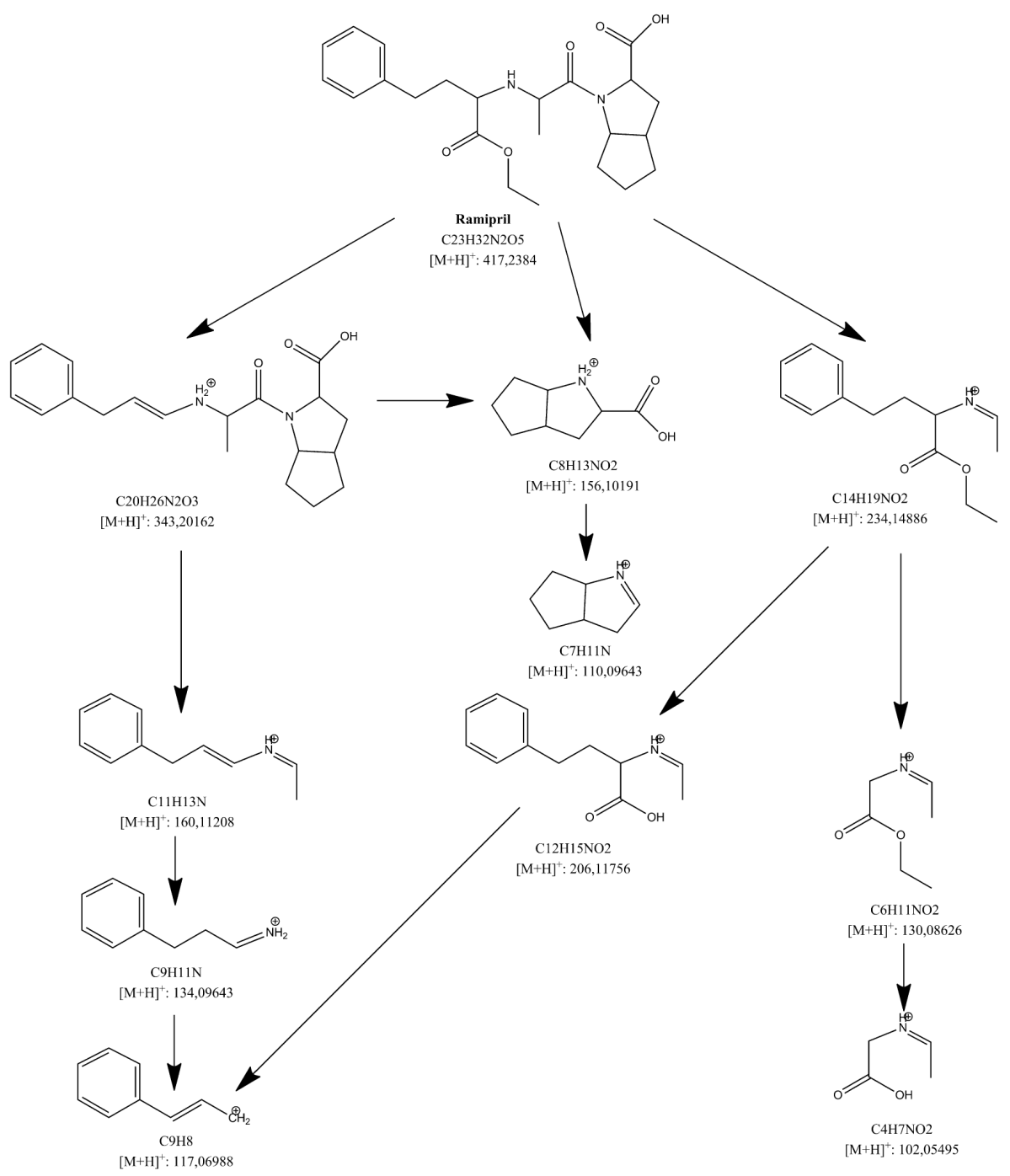

Fig. 3. Proposed fragmentation pathway of ramipril.

deuterated standards or substances very similar to ramipril, trandolaprilat or enalapril, mostly obtained very high recoveries. Table $\mathrm{V}$ shows that only in this work the method used for ramipril determination was high resolution mass spectrometry. Aplication of QTOF enabled us to achieve multiple levels of fragmentation $\left(\mathrm{MS}^{n}\right)$ for the elucidation of ramipril structure. It has not been described in any of the cited references. Despite the fact that most authors used a much more sensitive technique (LC-QQQ-MS/MS), the LLOQ achived in method is comparable to the other papers where $L L O Q$ was $0.1-2 \mathrm{ng} \mathrm{mL}^{-1}$. The method developed can be applied to clinical and toxicological studies. 
P. Szpot and G. Buszewicz: Determination of ramipril in human plasma and its fragmentation by UPLC-Q-TOF-MS with positive electrospray ionization, Acta Pharm. 65 (2015) 159-169.

Table V. Comparison of methods for determination of ramipril in biological samples

\begin{tabular}{|c|c|c|c|c|c|}
\hline Matrix & Sample preparation & Method & Recovery / IS & $\begin{array}{c}\mathrm{LOQ} \\
\left(\mathrm{ng} \mathrm{mL}^{-1}\right)\end{array}$ & Ref. \\
\hline $\begin{array}{l}\text { Plasma } \\
\text { and urine }\end{array}$ & SPE (C18 Bond Elut) & GC-MS & -/ ramipril-D4 & - & (8) \\
\hline Plasma & SPE (C18 Bond Elut) & LC-QQQ-MS/MS & $\begin{array}{l}84.2-87.4 \% \text { / } \\
\text { ramipril-D3 }\end{array}$ & 0.1 & (9) \\
\hline Plasma & SPE (DVBLP cartridge) & LC-QQQ-MS/MS & $\begin{array}{l}90.1-104.1 \% / \\
\text { trandolaprilat and } \\
\text { hydrochlorothiazide }\end{array}$ & 0.1 & (10) \\
\hline Plasma & $\begin{array}{l}\text { protein precipitation } \\
\text { with } \mathrm{MeOH} / 0.1 \mathrm{M} \mathrm{ZnSO}_{4} \\
(4: 1, v / v) \text { solution }\end{array}$ & LC-QQQ-MS/MS & $\begin{array}{l}68.5 \% / \\
\text { doxepin-D3 }\end{array}$ & 0.5 & (12) \\
\hline Plasma & $\begin{array}{l}\text { LLE (methyl tertiary } \\
\text { butyl ether : } \\
\text { dichloromethane; } 85: 15 \text { ) }\end{array}$ & LC-QQQ -MS/MS & $\begin{array}{l}77.7-82.9 \% \text { / } \\
\text { carbamazepine }\end{array}$ & 2 & (14) \\
\hline Plasma & LLE (ethyl acetate) & LC-QQQ-MS/MS & $\begin{array}{l}\text { 64.5-69.7 \% / } \\
\text { enalapril }\end{array}$ & 0.1 & (15) \\
\hline Plasma & $\begin{array}{l}\text { SPE (Oasis HLB } \\
\text { extraction cartridge) }\end{array}$ & LC-QQQ-MS/MS & 88.7 \% / enalapril & 0.5 & (16) \\
\hline Serum & $\begin{array}{l}\text { protein precipitation } \\
\text { with } \mathrm{MeOH}\end{array}$ & LC-QQQ-MS/MS & $\begin{array}{l}\text { 83.4-90.7 \% / } \\
\text { enalapril }\end{array}$ & 0.1 & (17) \\
\hline Plasma & $\begin{array}{l}\text { SPE (Oasis HLB } \\
\text { extraction cartridge) }\end{array}$ & LC-QQQ-MS/MS & $\begin{array}{l}81.3-90.1 \% \text { / } \\
\text { irbesartan, } \\
\text { metolazone }\end{array}$ & 0.1 & (26) \\
\hline Plasma & $\begin{array}{l}\text { protein precipitation with } \\
\text { acetonitrile combined } \\
\text { with LLE (ethyl acetate) }\end{array}$ & LC-Q-TOF-MS & $\begin{array}{l}\text { 65.3-97.3 \% / } \\
\text { diazepam-D5 }\end{array}$ & 0.5 & $\begin{array}{l}\text { This } \\
\text { article }\end{array}$ \\
\hline
\end{tabular}

\section{CONCLUSIONS}

This paper presents validation of the UPLC-Q-TOF-MS method for determination of ramipril in human plasma. The proposed method was simple, specific, precise and sensitive with a minimal quantity of matrix through the use of precipitation combined with extraction. Despite the fact that the Q-TOF analyzer is commonly considered to be a device for qualitative and not for quantitative analysis because of its limited linearity, our study shows that it can be successfully used also for quantitative analysis in a limited range of concentrations. This method can be used in toxicological and reaction kinetics studies of ramipril.

Acknowledgements. - The authors are greatful to Agnieszka Mądro PhMD, Chair, and Department of Gastroenterology with Endoscopic Unit, Medical University of Lublin, Poland, for providing the clinical material. 


\section{REFERENCES}

1. K. V. Gowda, U. Mandal, P. S. Selvan, W. D. S. Solomon, A. Ghosh, A. K. Sarkar, S. Agarwal, T. N. Rao and T. K. Pal, Liquid chromatography tandem mass spectrometry method for simultaneous determination of metoprolol tartrate and ramipril in human plasma, J. Chromatogr. B 858 (2007) 13-21; DOI: 10.1016/j.jchromb.2007.07.047.

2. H. E. Abdellatef, M. M. Ayad and E. A. Taha, Spectrophotometric and atomic absorption spectrometric determination of ramipril and perindopril through ternary complex formation with eosin and Cu(II), J. Pharmacol. Biomed. Anal. 18 (1999) 1021-1027; DOI: 10.1016/S0731-7085(98)00113-7.

3. F. A. El Yazbi, M. E. Mahrous, H. H. Hammud, G. M. Sonji and M. N. Sonji, Comparative spectrophotometric, spectrofluorometric, and high-performance liquid chromatographic study for the quantitative determination of the binary mixture felodipine and ramipril in pharmaceutical formulations, Anal. Lett. 41 (2008) 853-870; DOI: 10.1080/00032710801934643.

4. A. S. Kamatchi, T. Vetrichelvan and D. Venkappaya, Simultaneous estimation of ramipril, acetylsalicylic acid and atorvastatin calcium by chemometrics assisted UV-spectrophotometric method in capsules, Acta Pharm. 61 (2011) 283-296; DOI: 10.2478/v10007-011-0027-1.

5. S. Orlandini, R. Gotti, I. Giannini, B. Pasquini and S. Furlanetto, Development of a capillary electrophoresis method for the assay of ramipril and its impurities: An issue of cis-trans isomerization, J. Chromatogr. A 1218 (2011) 2611-2617; DOI: 10.1016/j.chroma.2011.02.062.

6. Y. T. Wu, T. M. Cham and T. R. Tsai, Development of HPLC with photo-diode array method for the determination of ramipril in tablets using factorial design, J. Chin. Chem. Soc. 61 (2014) press; DOI: $10.1002 /$ jccs.201400130.

7. S. Mehta, S. Singh, K. Chikhalia, P. Mehta and T. Dadhania, Determination of assay and uniformity of content of ramipril and telmisartan in their multiple dosage forms by a developed and validated supercritical fluid chromatographic technique, Anal. Methods 6 (2014) 7068-7074; DOI: 10.1039/C4AY01201A.

8. B.-A. Persson, C. Fakt, M. Ervik and M. Ahnoff, Interference from a glucuronide metabolite in the determination of ramipril and ramiprilat in human plasma and urine by gas chromatographymass spectrometry, J. Pharmacol. Biomed. Anal. 40 (2006) 794-798; DOI: 10.1016/j.jpba.2005.08.013.

9. A. Tan, W. Jin, F. Deng, S. Hussain, A. Musuku and R. Massé, Bioanalytical method development and validation using incurred samples - simultaneous quantitation of ramipril and ramiprilat in human EDTA plasma by LC-MS/MS, J. Chromatogr. B 877 (2009) 3673-3680; DOI: 10.1016/j. jchromb.2009.09.017.

10. V. K. Gupta, R. Jain, O. Lukram, S. Agarwal and A. Dwivedi, Simultaneous determination of ramipril, ramiprilat and telmisartan in human plasma using liquid chromatography tandem mass spectrometry, Talanta 83 (2011) 709-716; DOI: 10.1016/j.talanta.2010.10.011.

11. R. Varga, Z. Eke and K. Torkos, Identification of phase I metabolites of cardiovascular and antiulcer drugs in surface water samples with liquid-chromatography-mass spectrometry methods, Talanta 85 (2011) 1920-1926; DOI: 10.1016/j.talanta.2011.07.020.

12. O. Gonzales, R. M. Alonso, N. Ferreirós, W. Weinmann, R. Zimmermann and S. Dresen, Development of an LC-MS/MS method for the quantitation of 55 compounds prescribed in combined cardiovascular therapy, J. Chromatogr. B 879 (2011) 243-252; DOI: 10.1016/j.jchromb.2010.12.007.

13. D. S. Jain, G. Subbaiah, M. Sanyal, U. C. Pande and P. Shrivastav, First LC-MS/MS electrospray ionization validated method for the quantification of perindopril and its metabolite perindoprilat in human plasma and its application to bioequivalence study, J. Chromatogr. B 837 (2006) 92-100; DOI: 10.1016/j.jchromb.2006.04.008.

14. J. R. Patel, T. M. Pethani, A. N. Vachhani, N. R. Sheth and A. V. Dudhrejiya, Development and validation of bioanalytical method for simultaneous estimation of ramipril and hydrochlorothia- 
zide in human plasma using liquid chromatography-tandem mass spectrometry, J. Chromatogr. $B$ 970 (2014) 53-59; DOI: 10.1016/j.jchromb.2014.08.023.

15. B. Yuan, X. Wang, F. Zhang, J. Jia and F. Tang, Simultaneous determination of ramipril and active metabolite ramiprilat in human plasma by LC-MS-MS, Chromatographia 68 (2008) 533-539; DOI: 10.1365/s10337-008-0757-5.

16. Z. Zhu, A. Vachareau and L. Neirinck, Liquid chromatography-mass spectrometry method for determination of ramipril and its active metabolite ramiprilat in human plasma, J. Chromatogr. $B$ 779 (2002) 297-306.

17. X.-Y. Lu, J.-Z. Shen-Tu and J. Liu, High-performance liquid chromatography-mass spectrometric analysis of ramipril and its active metabolite ramiprilat in human serum: Application to a pharmacokinetic study in the Chinese volunteers, J. Pharmacol. Biomed. Anal. 40 (2006) 478-483; DOI: 10.1016/j.jpba.2005.07.054.

18. S. Broecker, F. Pragst, A. Bakdash, S. Herre and M. Tsokos, Combined use of liquid chromatography-hybrid quadrupole time-of-flight mass spectrometry (LC-QTOF-MS) and high performance liquid chromatography with photodiode array detector (HPLC-DAD) in systematic toxicological analysis, Forensic Sci. Int. 212 (2011) 215-226; DOI: 10.1016/j.forsciint.2011.06.014.

19. R. N. Tiwari and C. G. Bonde, LC, LC-MS/TOF and MS ${ }^{\mathrm{n}}$ studies for the identification and characterization of degradation products of nelfinavir mesylate, J. Pharmacol. Biomed. Anal. 55 (2011) 435-445; DOI: 10.1016/j.jpba.2011.02.020.

20. B. Raju, M. Ramesh, R. Srinivas, S. S. Raju and Y. Venkateswarlu, Identification and characterization of stressed degradation products of prulifloxacin using LC-ESI-MS/Q-TOF, MS ${ }^{\mathrm{n}}$ experiments: Development of a validated specific stability-indicating LC-MS method, J. Pharmacol. Biomed. Anal. 56 (2011) 560-568; DOI: 10.1016/j.jpba.2011.06.021.

21. V. Kumar, S. Malik and S. Singh, Polypill for the treatment of cardiovascular diseases: Part 2. LC-MS/TOF characterization of interaction/degradation products of atenolol/lisinopril and aspirin, and mechanisms of formation thereof, J. Pharmacol. Biomed. Anal. 48 (2008) 619-628; DOI: 10.1016/j.jpba.2008.06.003.

22. R. Skibiński, A study of photodegradation of quetiapine by the use of LC-MS/MS method, Cent. Eur. J. Chem. 10 (2012) 232-240; DOI: 10.2478/s11532-011-0133-4.

23. P. Szpot, K. Bańka, G. Buszewicz and R. Mądro, Determination of imazalil and thiabendazole by UPLC- Q-TOF-MS - an analysis of a grapefruit extract-containing dietary supplement, Curr. Issues Pharm. Med. Sci. 25 (2012) 401-403; DOI: 10.12923/j.2084-980X/25.4/a.13.

24. Y. Picó, M. la Ferré, C. Soler and D. Barceló, Identification of unknown pesticides in fruits using ultra-performance liquid chromatography-quadrupole time-of-flight mass spectrometry: Imazalil as a case study of quantification, J. Chromatogr. A 1176 (2007) 123-134; DOI: 10.1016/j.chroma.2007.10.071.

25. M. Dendeni, N. Cimetiere, A. Amrane and N. Ben Hamida, Impurity profiling of trandolapril under stress testing structure elucidation of by-products and development of degradation pathway, Int. J. Pharm. 438 (2012) 61-70; DOI: 10.1016/j.ijpharm.2012.08.048.

26. R. Dubey and M. Ghosh, Simultaneous determination and pharmacokinetic study of losartan, losartan carboxylic, ramipril, ramiprilat and hydrochlorothiazide in rat plasma by liquid chromatography/tandem mass spectrometry method, Sci. Pharm. (2014) in press; DOI: 10.3797/scipharm.1410-15. 